\title{
Folate, DNA methylation and colo-rectal cancer
}

\author{
Maria Pufulete*, Peter W. Emery and Thomas A. B. Sanders \\ Nutrition Food and Health Research Centre, King's College London, 150 Stamford Street, \\ London SE1 9NN, UK
}

\begin{abstract}
Prospective cohort and case-control studies suggest an association between low folate intake and increased risk of colo-rectal adenoma and cancer. Some, but not all, animal studies indicate that folate supplementation protects against the development of colo-rectal neoplasms, although supraphysiological folate doses have been shown to enhance tumour growth. Folate is a methyl donor for nucleotide synthesis and biological methylation reactions, including DNA methylation. A low dietary folate intake may increase the risk of colo-rectal neoplasia by inducing genomic DNA hypomethylation, which can affect the expression of proto-oncogenes and tumour suppressor genes associated with the development of cancer. Common polymorphisms in genes involved in the methylation pathway, such as methylenetetrahydrofolate reductase and methionine synthase, have been shown to influence risk of colo-rectal neoplasia, with interactions dependent on folate status and/or alcohol intake, which is known to antagonise methyl group availability. There is some evidence to show that DNA from normal-appearing colo-rectal mucosa in individuals with colo-rectal cancer is hypomethylated. In a case-control study DNA methylation in normal-appearing colo-rectal mucosa has been shown to be lower in individuals with colo-rectal cancer $(P=0.08)$ and colo-rectal adenoma $(P=0.009)$ than in controls free of colorectal abnormalities. Human intervention trials to date suggest that supraphysiological doses of folate can reverse DNA hypomethylation in colo-rectal mucosa of individuals with colo-rectal neoplasia. In a double-blind randomised placebo-controlled study folate supplementation at physiological doses has been shown to increase DNA methylation in leucocytes $(P=0.05)$ and colonic mucosa $(P=0 \cdot 09)$. Further studies are required to confirm these findings in larger populations and to define abnormal ranges of DNA methylation.
\end{abstract}

Folate: DNA methylation: Colo-rectal neoplasia

\section{Diet and colo-rectal neoplasia}

Colo-rectal cancer (CC) is the second most common cancer in Western societies (Muir et al. 1987). There is marked variation in incidence throughout the world, with high rates in industrialised regions such as Australia, New Zealand, USA, Japan and Western Europe, and low rates in regions such as Africa, China and other parts of Asia (Parkin et al. 1999). The majority of CC are believed to be sporadic, and only about $15 \%$ are due to dominantly inherited mutations in susceptibility genes (Cannon-Albright et al. 1988; Houlston et al. 1992). Neoplastic transformation of the colonic mucosa is characterised by increased cell proliferation, adenomatous polyp formation and growth, malignant transformation and invasion (Fearon \& Vogelstein, 1990). This transformation process is accompanied by many genetic and epigenetic changes occurring at various stages of disease progression.

Diet is thought to play a role in the development of CC. Ecological studies suggest that the adoption of a Western diet, characterised by high intakes of fat and lower intakes of starchy foods, is associated with increased risk. There is now moderately consistent evidence that diets containing high intakes of red meat and low intakes of vegetables are associated with increased risk (Department of Health, 1998). In a recent study in which a food-frequency questionnaire specifically designed to assess folate intake was validated against a $7 \mathrm{~d}$ weighed food intake record and biomarkers of folate status was validated, vegetables were shown to be a major source of folate in the diet (Pufulete et al. 2002b). Among the components in vegetables that may be responsible for the observed protective effect is the

\footnotetext{
Abbreviations: CA, colo-rectal adenoma; CBS, cystathionine- $\beta$-synthase; CC, colo-rectal cancer; MS, methionine synthase; MTHFR, methylenetetrahydrofolate reductase.

*Corresponding author: Maria Pufulete, fax +44 207848 4185, email maria.pufulete@kcl.ac.uk
} 
DNA biosynthesis

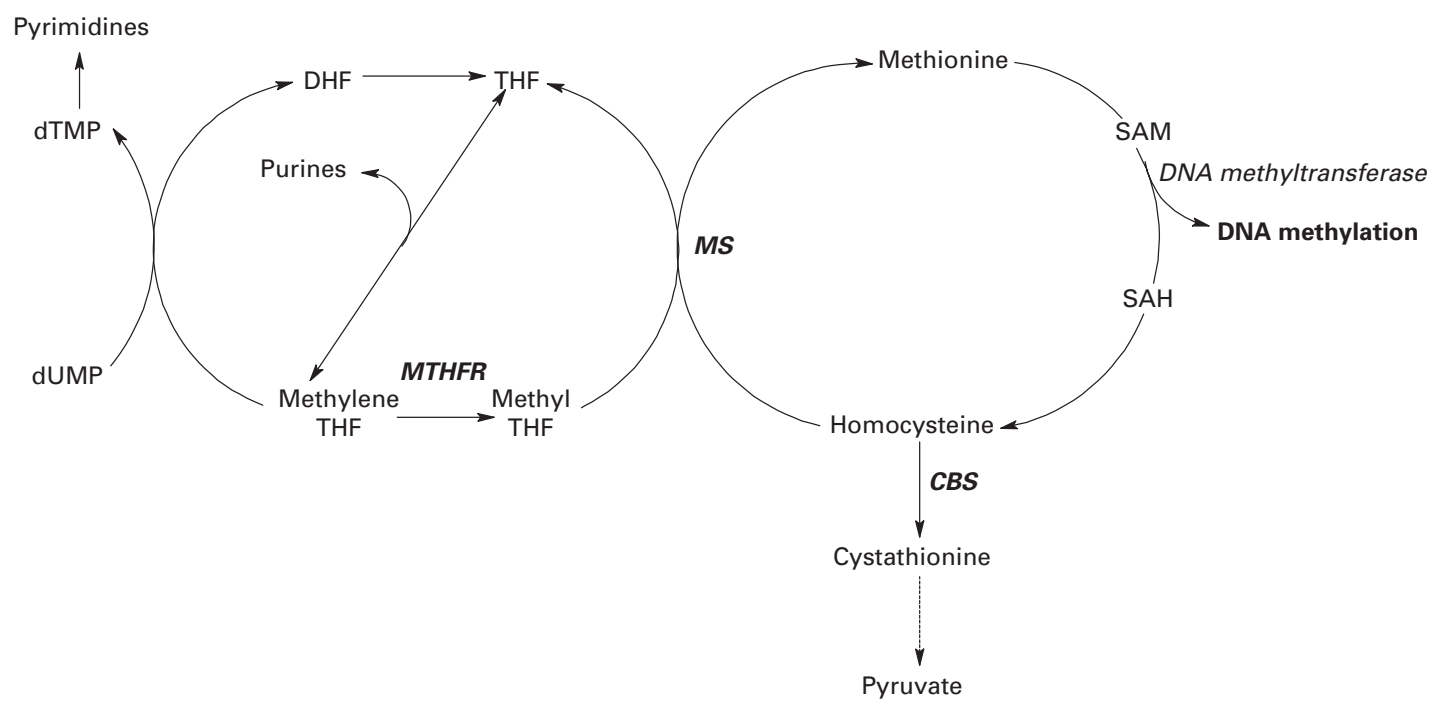

Fig. 1. Competing pathways in folate metabolism. dTMP, deoxythymidine monophosphate; dUMP, deoxyuridine monophosphate; DHF, dihydrofolate; THF, tetrahydrofolate; MTHFR, methylenetetrahydrofolate reductase; MS, methionine synthase; SAM, S-adenosylmethionine; SAH, S-adenosylhomocysteine; CBS, cystathionine- $\beta$-synthase.

water-soluble B-vitamin, folate, which has recently attracted a lot of attention because of its important role in DNA metabolism, which is markedly altered in carcinogenesis.

\section{Biochemical function of folate}

Folate donates and accepts $\mathrm{C}_{1}$ units, a reaction that is essential for the synthesis of DNA, RNA and glycine, and maintaining the methylation cycle (Fig. 1). Deficiency results in ineffective DNA synthesis, reduced cell proliferation and impaired cellular physiology.

Folate, in the form of 5,10-methylenetetrahydrofolate is required for purine synthesis and the de novo synthesis of thymidylate from deoxyuridylate. The regeneration of methionine from homocysteine in the methylation cycle requires a methyl group from 5-methyltetrahydrofolate, in a reaction catalysed by the vitamin $\mathrm{B}_{12}$-dependent enzyme, methionine synthase (MS). The activated form of methionine, $S$-adenosylmethionine, donates the methyl group derived from folate in over eighty methylation reactions, including DNA methylation, which is a fundamental mechanism for the epigenetic control of gene expression and maintenance of genomic integrity.

At first glance, folate seems an unlikely candidate as a protective agent against cancer. It has been known for some time that folate can promote tumour growth, an observation that has led to the development of anti-folate agents such as methotrexate, which is used in cancer chemotherapy (Kamen, 1997). Folate plays a key role in DNA replication and cell division; therefore, reducing the amount of folate in tissues with rapidly replicating cells will impair these processes. However, healthy tissues also require an adequate folate pool to maintain normal DNA synthesis and function, and a disruption of these processes can lead to genomic instability, creating an environment that potentiates risk factors for carcinogenesis.

\section{Folate intake and risk of colo-rectal neoplasia}

Prospective cohort (Giovannucci et al. 1995, 1998; Glynn et al. 1996; Su \& Arab 2001; Fuchs et al. 2002; Konings et al. 2002; Terry et al. 2002) and case-control (Benito et al. 1991; Freudenheim et al. 1991; Meyer \& White, 1993; Ferraroni et al. 1994; La Vecchia et al. 1997; White et al. 1997) studies that have investigated the effect of dietary folate intake on CC risk generally show a reduction in risk (about $35 \%$ overall) in subjects with the highest dietary folate intake compared with those with the lowest intake. These effects appeared to be greatest in subjects with the lowest alcohol intake (Giovannucci et al. 1995; Glynn et al. 1996). In some studies regular use of folic acid supplements was associated with the protective effect (Giovannucci et al. 1998; Fuchs et al. 2002). Only four studies showed no protective effect of folate (Boutron-Ruault et al. 1996; Kato et al. 1999; Levi et al. 2000; Flood et al. 2002). A high folate intake has also been associated with decreased risk of colo-rectal adenoma (CA; Giovannucci et al. 1993; Boutron-Ruault et al. 1996; Tseng et al. 1996; Baron et al. 1998). CA is believed to be a precursor of CC (Fenoglio \& Lane, 1974) and is considered an intermediary stage of colo-rectal neoplasia. Folate supplementation $(1 \mathrm{mg} / \mathrm{d})$ has been shown to decrease CA recurrence by $46 \%$ in thirty-one subjects with previously resected CA (Paspatis \& Karamanolis, 1994).

\section{Biomarkers of folate status and risk of colo-rectal neoplasia}

The relationship between biomarkers of folate status and risk of colo-rectal neoplasia is less well defined. Two nested case-control studies provide conflicting information; the first showed that serum folate concentrations were significantly lower $(P<0 \cdot 001)$ in women with $\mathrm{CC}$ 
compared with controls (Kato et al. 1999), while the second showed no differences in serum folate concentrations between male smokers with and without CC (Glynn et al. 1996). In a large case-control study investigating the relationship between biomarkers of folate status and risk of $\mathrm{CA}$, serum and erythrocyte folate concentrations were significantly different $(P<0.05)$ between cases and controls, but only in men (Bird et al. 1995). On the other hand, Paspatis et al. (1995) showed that erythrocyte (but not serum) folate concentrations were significantly lower in subjects with CA compared with controls $(P<0 \cdot 01)$.

Two studies have reported data on the relationship between plasma homocysteine concentration, which rises in folate depletion and is thought to be a sensitive indicator of cellular folate depletion, and risk of colo-rectal neoplasia. The first study showed that plasma homocysteine concentrations were significantly higher in women with CC compared with controls ( $P=0 \cdot 04$; Kato et al. 1999), while a smaller study showed that although plasma homocysteine concentration was higher in subjects with CA compared with controls $(P=0 \cdot 04)$, blood folate concentrations were similar in both groups (Kim et al. 1998).

\section{Polymorphisms of enzymes involved in the methylation cycle and risk of colo-rectal neoplasia}

The effect of common polymorphisms in key enzymes involved in the methylation pathway (methylenetetrahydrofolate reductase (MTHFR) $677 \mathrm{C} \rightarrow \mathrm{T}, \mathrm{MS} 2756 \mathrm{~A} \rightarrow \mathrm{G}$ and cystathionine- $\beta$-synthase (CBS) 844ins68) on $\mathrm{CC}$ risk has been investigated in several studies. MTHFR is a critical enzyme in folate metabolism (Fig. 1), catalysing the conversion of 5,10-methylenetetrahydrofolate to 5methyltetrahydrofolate. The $677 \mathrm{C} \rightarrow \mathrm{T}$ mutation decreases MTHFR activity (Frosst et al. 1995), leading to reduced plasma folate and increased plasma homocysteine.

Three studies have reported a decreased risk of $\mathrm{CC}$ in individuals homozygous for the MTHFR $677 \mathrm{C} \rightarrow \mathrm{T}$ mutation compared with those not carrying the mutation, although the protective effect was absent in those with folate deficiency or high alcohol intake (Chen et al. 1996; Ma et al. 1997; Slattery et al. 1999). Studies in subjects with CA show similar interactions between the MTHFR $677 \mathrm{C} \rightarrow \mathrm{T}$ mutation, folate status and alcohol intake (Ulrich et al. 1999; Levine et al. 2000; Ulvik et al. 2001), suggesting that the homozygous mutation increases CA risk under conditions of low folate status or high alcohol intake. The MS 2756A $\rightarrow \mathrm{G}$ mutation has also been associated with a small nonsignificant increase in risk of developing $\mathrm{CC}$ and $\mathrm{CA}$ (Chen et al. 1998; Ma et al. 1999). MS is the vitamin $\mathrm{B}_{12}$-dependent enzyme that catalyses the conversion of homocysteine to methionine in the methylation cycle (Fig. 1). This mutation can also lead to increased levels of plasma homocysteine (Harmon et al. 1999). One study has also reported a lower frequency of the CBS 844 ins68 mutation in CC subjects compared with controls, particularly in cases with proximal colon tumours (Shannon et al. 2002). CBS irreversibly removes homocysteine from the methylation cycle by transulfuration to cystathionine, a pathway that may become more important when folate supply is limited.

It has been proposed that the MTHFR $677 \mathrm{C} \rightarrow \mathrm{T}$ mutation reduces $\mathrm{CC}$ risk by influencing the DNA synthesis pathway (Fig. 1). As the mutation decreases MTHFR activity, there is inefficient conversion of 5,10methylenetetrahydrofolate to 5-methyltetrahydrofolate. Increased levels of 5,10-methylenetetrahydrofolate, which is a cofactor for nucleotide synthesis, may increase nucleotide precursor pools resulting in more efficient DNA synthesis and repair. When there is an adequate supply of methyl groups from folate the negative effects of these polymorphisms on DNA methylation may be overcome. Conversely, when the supply of methyl groups is low, both DNA methylation and synthesis may be impaired, increasing the risk of neoplasia. A high alcohol intake can also overcome the apparent protective effect of the mutations because it reduces the availability of methyl groups (Finkelstein et al. 1974) and can cleave folate (Shaw et al. 1989), impair folate absorption (Romero et al. 1981) and increase folate excretion (Eichner \& Hillman, 1971). Alcohol has also been shown to interfere with MS activity (Barak et al. 2001).

\section{Animal studies}

Studies in animal models of cancer generally complement the epidemiological evidence, although results have not been entirely consistent. In controlled experiments using the dimethylhydrazine rodent model of $\mathrm{CC}$, folate depletion increased tumour incidence following injection with dimethylhydrazine, a colo-rectal carcinogen (Cravo et al. 1992; Kim et al. 1996b). In the study by Kim et al. (1996b) folate supplementation of up to four times the dietary requirement was associated with reduced incidence of tumour growth. Studies that have used the azoxymethane rodent model of $\mathrm{CC}$ have shown no effect of folate supplementation on tumour incidence and aberrant crypt foci (an early precursor lesion and well-established intermediate biomarker of CC; Shivapurkar et al. 1995; Reddy et al. 1996). In some studies pharmacological doses of folate increased aberrant crypt foci (Wargovich et al. 1996) and tumour growth (Kim et al. 1996b), suggesting that in a strongly carcinogenic environment folate promotes tumour growth. This outcome has been observed in animals with well-established cancers (Baggott et al. 1992; Bills et al. 1992).

Studies have also assessed the role of folate intake on the development of intestinal polyps in a murine model of intestinal tumorigenesis that carries a heterozygous mutation in the adenomatous polyposis coli gene. The mutation predisposes to polyp formation throughout the small intestine and colon. These studies suggest that folate supplementation only suppresses polyp formation in the early stages of development (Song et al. 2000a,b). At later time points, folate supplementation was associated with an increase in the number of polyps, emphasising the protective role of folate only at the initiation stages of carcinogenesis. 


\section{Potential mechanisms by which folate may influence cancer risk}

A low folate status is thought to increase the risk of colo-rectal neoplasia by affecting both the DNA synthesis and methylation pathways (Mason \& Choi, 2000). Folate depletion can induce deoxynucleotide pool imbalance and uracil misincorporation in DNA in place of thymidine, which leads to abnormal DNA synthesis and repair. As the main focus of the present paper is on the role of folate in DNA methylation, it is beyond its scope to review the literature concerning the role of folate in DNA synthesis and repair.

\section{Alterations in DNA methylation}

DNA methylation is thought to play crucial roles in the regulation of gene expression and gene integrity. Of the four bases that make up DNA, only cytosine has the potential to be methylated in man and most mammals. Methylation occurs at the $5^{\prime}$ position of cytosine residues that form cytosine-guanine sequences ( $\mathrm{CpG}$ dinucleotides). The pattern of methylation in these sequences is a heritable, tissue- and species-specific change (Razin \& Szyf, 1984). Most $\mathrm{CpG}$ dinucleotides are clustered in small stretches of DNA known as $\mathrm{CpG}$ islands. As $\mathrm{CpG}$ islands are mainly found at the active sequences of genes (promoter regions), DNA methylation in these regions is an important determinant of gene expression. $\mathrm{CpG}$ islands are not usually methylated and de novo methylation in these regions is associated with gene silencing (Bird, 1986; Razin \& Cedar, 1991). Elsewhere in the genome, approximately $70-90 \%$ of CpG dinucleotides are methylated (Razin \& Szyf, 1984).

Apart from altering gene expression, DNA methylation is important in the conformational configuration and structural stability of DNA (Antequera et al. 1990; Keshet et al. 1986; Lewis \& Bird, 1991), binding of transcription factors and other proteins (Keshet et al. 1986; Boyes \& Bird, 1991; Levine et al. 1991), genomic imprinting (differential expression of parental alleles in normal development; $\mathrm{Li}$ et al. 1993) and mutations (Jones et al. 1992).

Collective evidence suggests that aberrations in DNA methylation are a cause rather than a consequence of carcinogenesis. Genomic and gene-specific DNA hypomethylation has been observed in cancer cells, including CC (Feinberg \& Vogelstein, 1983a; Goelz et al. 1985). DNA hypomethylation in proto-oncogenes may lead to their increased expression and has been reported in ras oncogenes (Feinberg \& Vogelstein, 1983b) and the c-myc oncogene (Sharrard et al. 1992). DNA hypomethylation is also associated with changes in interactions between DNA and methyl-specific proteins and changes in chromatin conformation, both of which can enhance the accessibility of specific sequences to DNA-damaging agents or endonucleases, thereby promoting genomic instability (Wolf \& Migeon, 1985; Keshet et al. 1986; Antequera et al. 1990; Lewis \& Bird, 1991). In cancer cells these hypomethylation events are frequently accompanied by hypermethylation in promoter regions of genes. DNA hypermethylation can silence tumour suppressor genes, including adenomatous polyposis coli, $p 16$ and $h \mathrm{MLH} 1$, and has been reported in
CA and CC (Sharrard et al. 1992; Hiltunen et al. 1997; Rashid et al. 2001; Yi et al. 2001).

Some $\mathrm{CpG}$ sequences, e.g. in genes such as the $p 53$ tumour suppressor gene, are not only sites of DNA methylation, but also mutational hotspots for cancers (Hollstein et al. 1991; Jones et al. 1992; Greenblatt et al. 1994). Most mutations that occur in $\mathrm{CpG}$ sequences are cytosine to thymine transitions. Several mechanisms have been proposed for this transition, including spontaneous deamination of methylated cytosine to thymine (Rideout et al. 1990), enzymic deamination of methylated cytosine to thymine (Jones et al. 1992; Yebra \& Bhagwat 1995) and enzymic deamination of unmethylated cytosine to uracil followed by methylation to thymine by methyltransferase, which binds to DNA and blocks repair of DNA mismatches (Jones et al. 1992; Shen et al. 1992; Yang et al. 1995).

\section{Animal studies on DNA methylation}

Diets deficient in methyl group donors (choline, folate, methionine and vitamin $\mathrm{B}_{12}$ ) have been shown to increase the risk of spontaneous and chemically-induced liver cancer in animals (Locker et al. 1986; Jones et al. 1992; Shen et al. 1992). Genomic and gene-specific ( $c$-myc, $c$-fos and $c$-ha-ras proto-oncogenes and the $p 53$ tumour suppressor gene) DNA hypomethylation occurs well before tumour growth (Wilson et al. 1984; Locker et al. 1986; Dizik et al. 1991; Cravo et al. 1992; Wainfan \& Poirier, 1992; Zapisek et al. 1992; Pogribny et al. 1995; Kim et al. 1996b; Pogribny et al. 1997). Studies have also reported altered levels of hepatic $S$-adenosylmethionine during methyl-group depletion or folate deficiency (Henning et al. 1989; Balaghi \& Wagner, 1993; Kim et al. 1994; Miller et al. 1994). It is not clear whether DNA hypomethylation occurs secondary to reduced levels of $S$-adenosylmethionine.

One study has shown that isolated folate deficiency leads to genomic DNA hypomethylation in rat liver (Balaghi \& Wagner, 1993), although data from subsequent studies suggest that folate deficiency alone does not induce genomic DNA hypomethylation in liver and colon DNA (Kim et al. 1995; Duthie et al. 2000; Le Leu et al. 2000). The reason could be that decreased $S$-adenosylmethionine availability enhances the activity of DNA methyltransferase, the enzyme responsible for DNA methylation (Shivapurkar \& Poirier, 1983; Henning et al. 1989).

However, isolated folate deficiency has been shown to induce hypomethylation at critical loci, which is thought to be more important in carcinogenesis than genomic DNA hypomethylation. The $p 53$ tumour suppressor gene is critically involved in carcinogenesis (Hollstein et al. 1991; Greenblatt et al. 1994); exons 5-8 of this gene contain large numbers of $\mathrm{CpG}$ nucleotides and are regarded as a mutational hotspot. Isolated folate deficiency has been shown to cause hypomethylation within exons 6 and 7 of the $p 53$ tumour suppressor gene in rat colon (Kim et al. 1996a, 1997). Dimethylhydrazine treatment of the folate-depleted rats also caused DNA hypomethylation in exon 8, which was effectively overcome by increasing levels of dietary folate in a dose-responsive manner (Kim et al. 1996a). Two studies in rats have shown a parallel increase in strand breaks with decreasing DNA methylation in this gene 
during folate deficiency (Pogribny et al. 1995; Kim et al. 1997). Folic acid supplementation has also been observed to prevent $p 53$ mutations in subjects with chronic ulcerative colitis, a disease associated with increased risk of CC (Shapiro et al. 1997).

\section{Human studies on DNA methylation}

Methylation abnormalities are not confined entirely to the neoplasm. One small study has shown that DNA from normal-appearing colo-rectal mucosa was significantly $(P<0.005)$ hypomethylated in twelve subjects with cancer compared with eight controls (Cravo et al. 1994). A study was carried out to investigate whether genomic DNA methylation in normal-appearing colo-rectal mucosa differed between thirty-five subjects with $\mathrm{CA}$, twenty-eight subjects with CC and seventy-six controls free of any colorectal abnormality. DNA methylation was determined by measuring $\left[{ }^{3} \mathrm{H}\right]$ methyl incorporation into DNA (Balaghi \& Wagner, 1993). Thus, an increase in $\left[{ }^{3} \mathrm{H}\right]$ methyl incorporation reflects a decrease in DNA methylation. After adjusting for various lifestyle factors (gender, age, BMI, smoking and alcohol intake) and polymorphisms in MTHFR, MS and CBS genes, DNA methylation in normalappearing colo-rectal mucosa was 26 and $30 \%$ lower in subjects with CA $(P=0.009)$ and $\mathrm{CC}(P=0.08)$ respectively compared with controls (Pufulete et al. 2003; Fig. 2).

Leucocyte DNA methylation has been shown to decrease in response to moderate folate depletion in post-menopausal women (Jacob et al. 1998; Rampersaud et al. 2000). DNA methylation was positively correlated with dietary folate intake and plasma folate (Jacob et al. 1998) and negatively correlated with plasma homocysteine (Rampersaud et al. 2000). This relationship was not confirmed in a study in younger subjects (Fenech et al. 1998). Two studies have also shown interactions between the MTHFR $677 \mathrm{C} \rightarrow \mathrm{T}$ mutation, folate status and DNA methylation in leucocytes (Stern et al. 2000; Friso et al. 2002).

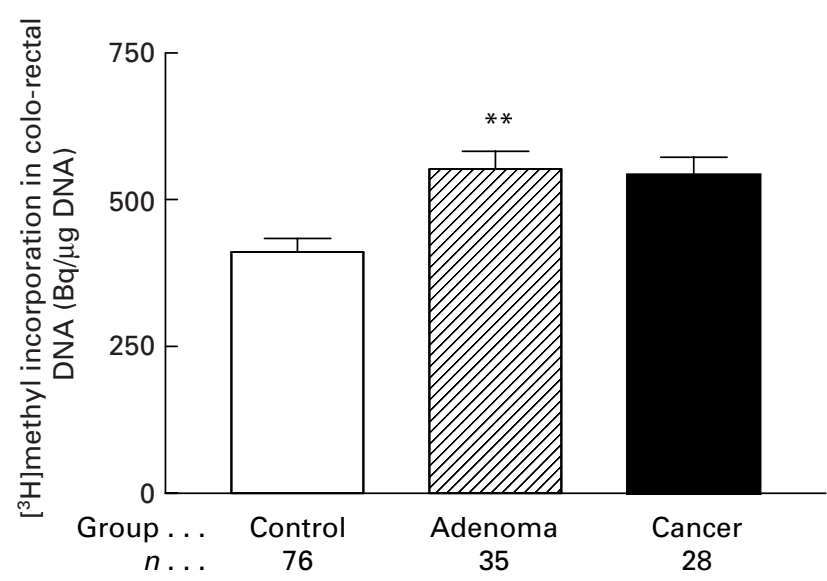

Fig. 2. Differences in $\mathrm{C}^{3} \mathrm{H}_{3}$ incorporation into DNA from normalappearing colo-rectal mucosa in subjects with colo-rectal adenoma (שns) and colo-rectal cancer $(\square)$ and in control subjects $(\square)$. Values are means with their standard errors represented by vertical bars. Mean value was significantly different from the control value: ${ }^{\star \star} P=0.009$. (From Pufulete et al. 2003.)
To date, there are no published studies that have assessed the influence of folate status on DNA methylation in colorectal mucosa. This relationship was investigated in a crosssectional study of sixty-one subjects (twenty-nine men and thirty-two women, 38-78 years) free from CA or CC. A score based on estimates of dietary intake, serum and erythrocyte folate concentrations was used to assess folate status. DNA hypomethylation was negatively correlated with folate status $(P=0 \cdot 01)$ and positively correlated with plasma homocysteine $(P=0 \cdot 03$; M Pufulete, $\mathrm{P}$ Emery and TAB Sanders, unpublished results).

\section{Folate supplementation and DNA methylation}

A small number of randomised double-blind placebocontrolled folate intervention trials in subjects with $\mathrm{CC}$ and CA have shown that folate supplementation can alter genomic DNA methylation. DNA hypomethylation in colorectal mucosa was reversed following 6 months of supplementation with folate $(10 \mathrm{mg} / \mathrm{d})$ in eleven subjects with either $\mathrm{CA}$ or $\mathrm{CC}$ following the removal of these lesions (Cravo et al. 1994). This outcome was not observed in the eleven subjects receiving placebo. A 3-month crossover study in twenty subjects with resected CA, using half the dose of folate $(5 \mathrm{mg} / \mathrm{d})$, showed a $40 \%$ increase in genomic DNA methylation in colo-rectal mucosa in subjects with a single adenoma $(P=0.05)$, although subjects with multiple adenomas did not respond (Cravo et al. 1998). In another study both folate supplementation $(5 \mathrm{mg} / \mathrm{d})$ and placebo for 1 year in twenty subjects with CA increased genomic DNA methylation and decreased strand breaks in exons 5-8 of the p53 tumour suppressor gene (Kim et al. 2001). The corresponding changes in the placebo group suggest that factors other than folate were responsible for the observed improvements.

A randomised placebo-controlled study was conducted in order to determine whether short-term (10 weeks) supplementation with a physiological dose of folate $(400 \mu \mathrm{g} / \mathrm{d})$ could increase DNA methylation in leucocytes and colorectal mucosa in thirty-one subjects with $\mathrm{CA}$. The results showed that after adjusting for various lifestyle factors (gender, age, BMI, smoking and alcohol intake) and polymorphisms in MTHFR $677 \mathrm{C} \rightarrow \mathrm{T}$ and MS 2756A $\rightarrow \mathrm{G}$ folate supplementation increased genomic DNA methylation by $31 \%(P=0.05$ for folate $v$. placebo; Fig. 3) and $25 \%$ $(P=0.09$ for folate $v$. placebo) respectively in leucocytes and colo-rectal mucosa (Pufulete et al. 2002a).

\section{Conclusion}

There is a growing body of evidence linking a low folate status to DNA hypomethylation and colo-rectal neoplasia. Further research is needed to clarify the mechanisms through which genomic DNA hypomethylation increases the risk of carcinogenesis, and to determine the betweenand within-person variation in DNA methylation and to define normal ranges of DNA methylation, thus providing a definition of 'hypomethylation'.

The proposed fortification programme in the UK is likely to improve folate status and lower plasma homocysteine concentration in the population, but more rigorous studies 


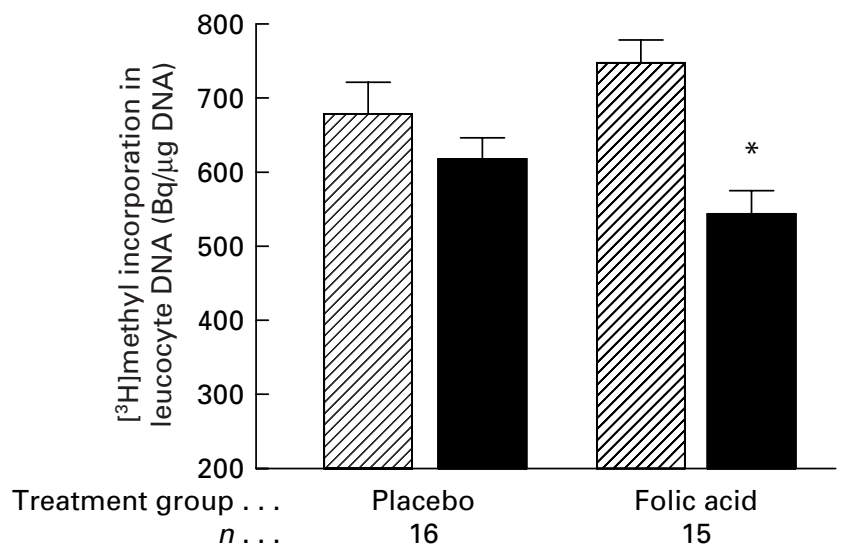

Fig. 3. Changes in $\left[{ }^{3} \mathrm{H}\right]$ methyl incorporation into leucocyte DNA following a 10-week period of supplementation with folic acid or placebo in thirty-one subjects with colo-rectal adenoma. (man), week 0 ; (四), week 10. Values are means with their standard errors represented by vertical bars. Change from baseline was significantly different from that for the placebo: ${ }^{*} P=0 \cdot 05$. (From Pufulete et al. 2002a.)

are required before speculating on any possible benefits on $\mathrm{CC}$ risk. There are currently three randomised double-blind placebo-controlled multi-centre folate chemo-prevention trials ongoing in the USA (New England Medical Centre Multicentre Study, Darmouth Medical Centre Multicentre Study and the Nurses' Health Study and Health Professionals Follow-up Study). All three studies are using supraphysiological doses of folate $(1-5 \mathrm{mg} / \mathrm{d})$ and the latter two studies have $\mathrm{CA}$ recurrence as an end point. It is likely that the folate fortification programme that began in the USA after some of these trials commenced will influence their outcome, so it is open to question whether these studies will clarify the effect of folate supplementation on colo-rectal neoplasia.

\section{References}

Antequera F, Boyes J \& Bird A (1990) High levels of de novo methylation and altered chromatin structure at $\mathrm{CpG}$ islands in cell lines. Cell 62, 503-514.

Baggott JE, Vaughn WH, Juliana MM, Eto I, Krumdieck CL \& Grubbs CJ (1992) Effects of folate deficiency and supplementation on methylnitrosourea-induced rat mammary tumors. Journal of the National Cancer Institute 84, 1740-1744.

Balaghi M \& Wagner C (1993) DNA methylation in folate deficiency: use of $\mathrm{CpG}$ methylase. Biochemical and Biophysical Research Communications 193, 1184-1190.

Barak AJ, Beckenhauer HC, Kharbanda KK \& Tuma DJ (2001) Chronic ethanol consumption increases homocysteine accumulation in hepatocytes. Alcohol 25, 77-81.

Baron JA, Sandler RS, Haile RW, Mandel JS, Mott LA \& Greenberg ER (1998) Folate intake, alcohol consumption, cigarette smoking, and risk of colorectal adenomas. Journal of the National Cancer Institute 90, 57-62.

Benito E, Stiggelbout A, Bosch FX, Obrador A, Kaldor J, Mulet M \& Munoz N (1991) Nutritional factors in colorectal cancer risk: a case-control study in Majorca. International Journal of Cancer 49, 161-167.
Bills ND, Hinrichs SH, Morgan R \& Clifford AJ (1992) Delayed tumor onset in transgenic mice fed a low-folate diet. Journal of the National Cancer Institute 84, 332-337.

Bird AP (1986) CpG-rich islands and the function of DNA methylation. Nature 321, 209-213.

Bird CL, Swendseid ME, Witte JS, Shikany JM, Hunt IF, Frankl HD, Lee ER, Longnecker MP \& Haile RW (1995) Red cell and plasma folate, folate consumption, and the risk of colorectal adenomatous polyps. Cancer Epidemiology Biomarkers and Prevention 4, 709-714.

Boutron-Ruault MC, Senesse P, Faivre J, Couillault C \& Belghiti C (1996) Folate and alcohol intakes: related or independent roles in the adenoma-carcinoma sequence? Nutrition and Cancer 26, $337-346$

Boyes J \& Bird A (1991) DNA methylation inhibits transcription indirectly via a methyl-CpG binding protein. Cell 64, 1123-1134.

Cannon-Albright LA, Skolnick MH, Bishop DT, Lee RG \& Burt RW (1988) Common inheritance of susceptibility to colonic adenomatous polyps and associated colorectal cancers. New England Journal of Medicine 319, 533-537.

Chen J, Giovannucci E, Hankinson SE, Ma J, Willett WC, Spiegelman D, Kelsey KT \& Hunter DJ (1998) A prospective study of methylenetetrahydrofolate reductase and methionine synthase gene polymorphisms, and risk of colorectal adenoma. Carcinogenesis 19, 2129-2132.

Chen J, Giovannucci E, Kelsey K, Rimm EB, Stampfer MJ, Colditz GA, Spiegelman D, Willett WC \& Hunter DJ (1996) A methylenetetrahydrofolate reductase polymorphism and the risk of colorectal cancer. Cancer Research 56, 4862-4864.

folate concentrations in the Framingham study. Journal of Nutrition 131, 3277-3280.

Cravo M, Fidalgo P, Pereira AD, Gouveia-Oliveira A, Chaves P, Selhub J, Mason JB, Mira FC \& Leitao CN (1994) DNA methylation as an intermediate biomarker in colorectal cancer: modulation by folic acid supplementation. European Journal of Cancer Prevention 3, 473-479.

Cravo ML, Mason JB, Dayal Y, Hutchinson M, Smith D, Selhub J \& Rosenberg IH (1992) Folate deficiency enhances the development of colonic neoplasia in dimethylhydrazine-treated rats. Cancer Research 52, 5002-5006.

Cravo ML, Pinto AG, Chaves P, Cruz JA, Lage P, Nobre LC \& Costa MF (1998) Effect of folate supplementation on DNA methylation of rectal mucosa in patients with colonic adenomas: correlation with nutrient intake. Clinical Nutrition 17, 45-49.

Department of Health (1998) Nutritional Aspects of the Development of Cancer. Report on Health and Social Subjects no. 48. London: H.M. Stationery Office.

Dizik M, Christman JK \& Wainfan E (1991) Alterations in expression and methylation of specific genes in livers of rats fed a cancer promoting methyl-deficient diet. Carcinogenesis $\mathbf{1 2}$, $1307-1312$.

Duthie SJ, Narayanan S, Brand GM \& Grant G (2000) DNA stability and genomic methylation status in colonocytes isolated from methyl-donor-deficient rats. European Journal of Nutrition 39, 106-111.

Eichner ER \& Hillman RS (1971) The evolution of anemia in alcoholic patients. American Journal of Medicine 50, 218-232.

Fearon ER \& Vogelstein B (1990) A genetic model for colorectal tumorigenesis. Cell 61, 759-767.

Feinberg AP \& Vogelstein B (1983a) Hypomethylation distinguishes genes of some human cancers from their normal counterparts. Nature 301, 89-92.

Feinberg AP \& Vogelstein B (1983b) Hypomethylation of ras oncogenes in primary human cancers. Biochemical and Biophysical Research Communications 111, 47-54. 
Fenech M, Aitken C \& Rinaldi J (1998) Folate, vitamin B12, homocysteine status and DNA damage in young Australian adults. Carcinogenesis 19, 1163-1171.

Fenoglio CM \& Lane N (1974) The anatomical precursor of colorectal carcinoma. Cancer 34, Suppl. 23, 819-823.

Ferraroni M, La Vecchia C, D'Avanzo B, Negri E, Franceschi S \& Decarli A (1994) Selected micronutrient intake and the risk of colorectal cancer. British Journal of Cancer 70, 1150-1155.

Finkelstein JD, Cello JP \& Kyle WE (1974) Ethanol-induced changes in methionine metabolism in rat liver. Biochemical and Biophysical Research Communications 61, 525-531.

Flood A, Caprario L, Chaterjee N, Lacey JV Jr, Schairer C \& Schatzkin A (2002) Folate, methionine, alcohol, and colorectal cancer in a prospective study of women in the United States. Cancer Causes and Control 13, 551-561.

Freudenheim JL, Graham S, Marshall JR, Haughey BP, Cholewinski S \& Wilkinson G (1991) Folate intake and carcinogenesis of the colon and rectum. International Journal of Epidemiology 20, 368-374.

Friso S, Choi SW, Girelli D, Mason JB, Dolnikowski GG, Bagley PJ, Olivieri O, Jacques PF, Rosenberg IH, Corrocher R \& Selhub J (2002) A common mutation in the 5,10methylenetetrahydrofolate reductase gene affects genomic DNA methylation through an interaction with folate status. Proceedings of the National Academy of Science USA 99, 5606-5611.

Frosst P, Blom HJ, Milos R, Goyette P, Sheppard CA, Matthews RG, Boers GJ, den Heijer M, Kluijtmans LA \& van den Heuvel LP (1995) A candidate genetic risk factor for vascular disease: a common mutation in methylenetetrahydrofolate reductase. Nature Genetics 10, 111-113.

Fuchs CS, Willett WC, Colditz GA, Hunter DJ, Stampfer MJ, Speizer FE \& Giovannucci EL (2002) The influence of folate and multivitamin use on the familial risk of colon cancer in women. Cancer Epidemiology Biomarkers and Prevention 11, 227-234.

Giovannucci E, Rimm EB, Ascherio A, Stampfer MJ, Colditz GA \& Willett WC (1995) Alcohol, low-methionine-low-folate diets, and risk of colon cancer in men. Journal of the National Cancer Institute 87, 265-273.

Giovannucci E, Stampfer MJ, Colditz GA, Hunter DJ, Fuchs C, Rosner BA, Speizer FE \& Willett WC (1998) Multivitamin use, folate, and colon cancer in women in the Nurses' Health Study. Annals of Internal Medicine 129, 517-524.

Giovannucci E, Stampfer MJ, Colditz GA, Rimm EB, Trichopoulos D, Rosner BA, Speizer FE \& Willett WC (1993) Folate, methionine, and alcohol intake and risk of colorectal adenoma. Journal of the National Cancer Institute 85, 875-884.

Glynn SA, Albanes D, Pietinen P, Brown CC, Rautalahti M, Tangrea JA, Gunter EW, Barrett MJ, Virtamo J \& Taylor PR (1996) Colorectal cancer and folate status: a nested case-control study among male smokers. Cancer Epidemiology Biomarkers and Prevention 5, 487-494.

Goelz SE, Vogelstein B, Hamilton SR \& Feinberg AP (1985) Hypomethylation of DNA from benign and malignant human colon neoplasms. Science 228, 187-190.

Greenblatt MS, Bennett WP, Hollstein M \& Harris CC (1994) Mutations in the p53 tumor suppressor gene: clues to cancer etiology and molecular pathogenesis. Cancer Research 54, 4855-4878.

Harmon DL, Shields DC, Woodside JV, McMaster D, Yarnell JW, Young IS, Peng K, Shane B, Evans AE \& Whitehead AS (1999) Methionine synthase D919G polymorphism is a significant but modest determinant of circulating homocysteine concentrations. Genetics Epidemiology 17, 298-309.

Henning SM, McKee RW \& Swendseid ME (1989) Hepatic content of $S$-adenosylmethionine, $S$-adenosylhomocysteine and glutathione in rats receiving treatments modulating methyl donor availability. Journal of Nutrition 119, 1478-1482.

Hiltunen MO, Alhonen L, Koistinaho J, Myohanen S, Paakkonen M, Marin S, Kosma VM \& Janne J (1997) Hypermethylation of the APC (adenomatous polyposis coli)gene promoter region in human colorectal carcinoma. International Journal of Cancer 70, 644-648.

Hollstein M, Sidransky D, Vogelstein B \& Harris CC (1991) P53 mutations in human cancers. Science 253, 49-53.

Houlston RS, Collins A, Slack J \& Morton NE (1992) Dominant genes for colorectal cancer are not rare. Annals of Human Genetics 56, 99-103.

Jacob RA, Gretz DM, Taylor PC, James SJ, Pogribny IP, Miller BJ, Henning SM \& Swendseid ME (1998) Moderate folate depletion increases plasma homocysteine and decreases lymphocyte DNA methylation in postmenopausal women. Journal of Nutrition 128, 1204-1212.

Jones PA, Rideout WM III, Shen JC, Spruck CH \& Tsai YC (1992) Methylation, mutation and cancer. Bioessays 14, 33-36.

Kamen B (1997) Folate and antifolate pharmacology. Seminars in Oncology 24, S18.

Kato I, Dnistrian AM, Schwartz M, Toniolo P, Koenig K, Shore RE, Akhmedkhanov A, Zeleniuch-Jacquotte A \& Riboli E (1999) Serum folate, homocysteine and colorectal cancer risk in women: a nested case-control study. British Journal of Cancer 79, 1917-1922.

Keshet I, Lieman-Hurwitz J \& Cedar H (1986) DNA methylation affects the formation of active chromatin. Cell 44, 535-543.

Kim YI, Baik HW, Fawaz K, Knox T, Lee YM, Norton R, Libby E \& Mason JB (2001) Effects of folate supplementation on two provisional molecular markers of colon cancer: a prospective, randomized trial. American Journal of Gastroenterology 96, 184-195.

Kim YI, Christman JK, Fleet JC, Cravo ML, Salomon RN, Smith D, Ordovas J, Selhub J \& Mason JB (1995) Moderate folate deficiency does not cause global hypomethylation of hepatic and colonic DNA or c-myc-specific hypomethylation of colonic DNA in rats. American Journal of Clinical Nutrition 61, 1083-1090.

Kim YI, Fawaz K, Knox T, Lee YM, Norton R, Arora S, Paiva L \& Mason JB (1998) Colonic mucosal concentrations of folate correlate well with blood measurements of folate status in persons with colorectal polyps. American Journal of Clinical Nutrition 68, 866-872.

Kim YI, Miller JW, da Costa KA, Nadeau M, Smith D, Selhub J, Zeisel SH \& Mason JB (1994) Severe folate deficiency causes secondary depletion of choline and phosphocholine in rat liver. Journal of Nutrition 124, 2197-2203.

Kim YI, Pogribny IP, Basnakian AG, Miller JW, Selhub J, James SJ \& Mason JB (1997) Folate deficiency in rats induces DNA strand breaks and hypomethylation within the p53 tumor suppressor gene. American Journal of Clinical Nutrition 65, 46-52.

Kim YI, Pogribny IP, Salomon RN, Choi SW, Smith DE, James SJ \& Mason JB (1996a) Exon-specific DNA hypomethylation of the p53 gene of rat colon induced by dimethylhydrazine. Modulation by dietary folate. American Journal of Pathology 149, 1129-1137.

Kim YI, Salomon RN, Graeme-Cook F, Choi SW, Smith DE, Dallal GE \& Mason JB (1996b) Dietary folate protects against the development of macroscopic colonic neoplasia in a dose responsive manner in rats. Gut 39, 732-740.

La Vecchia C, Braga C, Negri E, Franceschi S, Russo A, Conti E, Falcini F, Giacosa A, Montella M \& Decarli A (1997) Intake of selected micronutrients and risk of colorectal cancer. International Journal of Cancer 73, 525-530. 
Le Leu RK, Young GP \& McIntosh GH (2000) Folate deficiency diminishes the occurrence of aberrant crypt foci in the rat colon but does not alter global DNA methylation status. Journal of Gastroenterology and Hepatology 15, 1158-1164.

Levi F, Pasche C, Lucchini F \& La Vecchia C (2000) Selected micronutrients and colorectal cancer. A case-control study from the canton of Vaud, Switzerland. European Journal of Cancer 36, 2115-2119.

Levine A, Cantoni GL \& Razin A (1991) Inhibition of promoter activity by methylation: possible involvement of protein mediators. Proceedings of the National Academy of Science USA 88, 6515-6518.

Levine AJ, Siegmund KD, Ervin CM, Diep A, Lee ER, Frankl HD \& Haile RW (2000) The methylenetetrahydrofolate reductase $677 \mathrm{C} \rightarrow \mathrm{T}$ polymorphism and distal colorectal adenoma risk. Cancer Epidemiology Biomarkers and Prevention 9, 657-663.

Lewis J \& Bird A (1991) DNA methylation and chromatin structure. FEBS Letters 285, 155-159.

Li E, Beard C \& Jaenisch R (1993) Role for DNA methylation in genomic imprinting. Nature 366, 362-365.

Locker J, Reddy TV \& Lombardi B (1986) DNA methylation and hepatocarcinogenesis in rats fed a choline-devoid diet. Carcinogenesis 7, 1309-1312.

Ma J, Stampfer MJ, Christensen B, Giovannucci E, Hunter DJ, Chen J, Willett WC, Selhub J, Hennekens CH, Gravel R \& Rozen $\mathrm{R}$ (1999) A polymorphism of the methionine synthase gene: association with plasma folate, vitamin B12, homocyst(e)ine, and colorectal cancer risk. Cancer Epidemiology Biomarkers and Prevention 8, 825-829.

Ma J, Stampfer MJ, Giovannucci E, Artigas C, Hunter DJ, Fuchs C, Willett WC, Selhub J, Hennekens CH \& Rozen R (1997) Methylenetetrahydrofolate reductase polymorphism, dietary interactions, and risk of colorectal cancer. Cancer Research 57, 1098-1102.

Mason JB \& Choi SW (2000) Folate and carcinogenesis: developing a unifying hypothesis. Advances in Enzyme Regulation 40, 127-141.

Meyer F \& White E (1993) Alcohol and nutrients in relation to colon cancer in middle-aged adults. American Journal of Epidemiology 138, 225-236.

Miller JW, Nadeau MR, Smith J, Smith D \& Selhub J (1994) Folatedeficiency-induced homocysteinaemia in rats: disruption of $S$-adenosylmethionine's co-ordinate regulation of homocysteine metabolism. Biochemical Journal 298, 415-419.

Muir C, Waterhouse J, Mack T, Powell J \& Whenal S (editors) (1987) Cancer Incidence in Five Continents, vol. 5. Lyon, France: International Agency for Research on Cancer.

Parkin DM, Pisani P \& Ferlay J (1999) Global cancer statistics. CA Cancer Journal for Clinicians 49, 33-64.

Paspatis GA, Kalafatis E, Oros L, Xourgias V, Koutsioumpa P \& Karamanolis DG (1995) Folate status and adenomatous colonic polyps. A colonoscopically controlled study. Diseases of the Colon and Rectum 38, 64-67.

Paspatis GA \& Karamanolis DG (1994) Folate supplementation and adenomatous colonic polyps. Diseases of the Colon and Rectum 37, 1340-1341.

Pogribny IP, Basnakian AG, Miller BJ, Lopatina NG, Poirier LA \& James SJ (1995) Breaks in genomic DNA and within the p53 gene are associated with hypomethylation in livers of folate/ methyl-deficient rats. Cancer Research 55, 1894-1901.

Pogribny IP, Miller BJ \& James SJ (1997) Alterations in hepatic $p 53$ gene methylation patterns during tumor progression with folate/methyl deficiency in the rat. Cancer Letters 115, 31-38.

Pufulete M, Al-Ghnaniem R, Khushal A, Leather AJM, Rennie JA, Emery PW \& Sanders TAB (2002a) Folic acid supplementation increases genomic DNA methylation in patients with colorectal adenoma. Proceedings of the Nutrition Society 61, 50A.

Pufulete M, Al-Ghnaniem R, Leather AJM, Appleby P, Gout S, Terry C, Emery PW \& Sanders TAB (2003) Folate status, genomic DNA hypomethylation and risk of colorectal adenoma and cancer: a case control study. Gastroenterology 124, 1240-1248.

Pufulete M, Emery PW, Nelson M, Sanders TAB (2002b) Validation of a food frequency questionnaire to assess folate intake. British Journal of Nutrition 87, 383-390.

Rampersaud GC, Kauwell GP, Hutson AD, Cerda JJ \& Bailey LB (2000) Genomic DNA methylation decreases in response to moderate folate depletion in elderly women. American Journal of Clinical Nutrition 72, 998-1003.

Rashid A, Shen L, Morris JS, Issa JP \& Hamilton SR (2001) $\mathrm{CpG}$ island methylation in colorectal adenomas. American Journal of Pathology 159, 1129-1135.

Razin A \& Cedar H (1991) DNA methylation and gene expression. Microbiology Reviews 55, 451-458.

Razin A \& Szyf M (1984) DNA methylation patterns. Formation and function. Biochimica et Biophysica Acta 782, 331-342.

Reddy BS, Wang C-X, Aliaga C, Rao CV, Lubet RA, Steele VE \& Kelloff GJ (1996) Potential chemopreventive activity of perrilyl alcohol and enhancement of experimental colon carcinogenesis by folic acid and genistein. Proceedings of the American Association of Cancer Research 37, 1849A.

Rideout WM III, Coetzee GA, Olumi AF \& Jones PA (1990) 5-Methylcytosine as an endogenous mutagen in the human LDL receptor and p53 genes. Science 249, 1288-1290.

Romero JJ, Tamura T \& Halsted CH (1981) Intestinal absorption of $[3 \mathrm{H}]$ folic acid in the chronic alcoholic monkey. Gastroenterology 80, 99-102.

Shannon B, Gnanasampanthan S, Beilby J \& Iacopetta B (2002) A polymorphism in the methylenetetrahydrofolate reductase gene predisposes to colorectal cancers with microsatellite instability. Gut 50, 520-524.

Shapiro BD, Goldblum JR, Hussain A \& Lashner BA (1997) The role of p53 mutations in colorectal cancer surveillance for ulcerative colitis. Gastroenterology 112, 1089A.

Sharrard RM, Royds JA, Rogers S \& Shorthouse AJ (1992) Patterns of methylation of the c-myc gene in human colorectal cancer progression. British Journal of Cancer 65, 667-672.

Shaw S, Jayatilleke E, Herbert V \& Colman N (1989) Cleavage of folates during ethanol metabolism. Role of acetaldehyde/ xanthine oxidase-generated superoxide. Biochemistry Journal 257, 277-280.

Shen JC, Rideout WM III \& Jones PA (1992) High frequency mutagenesis by a DNA methyltransferase. Cell 71, 1073-1080.

Shivapurkar N \& Poirier LA (1983) Tissue levels of $S$-adenosylmethionine and $S$-adenosylhomocysteine in rats fed methyldeficient, amino acid-defined diets for one to five weeks. Carcinogenesis 4, 1051-1057.

Shivapurkar N, Tang Z, Frost A \& Alabaster O (1995) Inhibition of progression of aberrant crypt foci and colon tumor development by vitamin $\mathrm{E}$ and beta-carotene in rats on a high-risk diet. Cancer Letters 91, 125-132.

Slattery ML, Potter JD, Samowitz W, Schaffer D \& Leppert M (1999) Methylenetetrahydrofolate reductase, diet, and risk of colon cancer. Cancer Epidemiology Biomarkers and Prevention 8, 513-518.

Song J, Medline A, Mason JB, Gallinger S \& Kim YI (2000a) Effects of dietary folate on intestinal tumorigenesis in the apcMin mouse. Cancer Research 60, 5434-5440.

Song J, Sohn KJ, Medline A, Ash C, Gallinger S \& Kim YI (2000b) Chemopreventive effects of dietary folate on intestinal polyps in Apc+/-Msh2-/- mice. Cancer Research 60, 3191-3199. 
Stern LL, Mason JB, Selhub J \& Choi SW (2000) Genomic DNA hypomethylation, a characteristic of most cancers, is present in peripheral leukocytes of individuals who are homozygous for the C677T polymorphism in the methylenetetrahydrofolate reductase gene. Cancer Epidemiology Biomarkers and Prevention 9, 849-853.

Su LJ \& Arab L (2001) Nutritional status of folate and colon cancer risk: evidence from NHANES I epidemiologic follow-up study. Annals of Epidemiology 11, 65-72.

Terry P, Jain M, Miller AB, Howe GR \& Rohan TE (2002) Dietary intake of folic acid and colorectal cancer risk in a cohort of women. International Journal of Cancer 97, 864-867.

Tseng M, Murray SC, Kupper LL \& Sandler RS (1996) Micronutrients and the risk of colorectal adenomas. American Journal of Epidemiology 144, 1005-1014.

Ulrich CM, Kampman E, Bigler J, Schwartz SM, Chen C, Bostick R, Fosdick L, Beresford SA, Yasui Y \& Potter JD (1999) Colorectal adenomas and the C677T MTHFR polymorphism: evidence for gene-environment interaction? Cancer Epidemiology Biomarkers and Prevention 8, 659-668.

Ulvik A, Evensen ET, Lien EA, Hoff G, Vollset SE, Majak BM \& Ueland PM (2001) Smoking, folate and methylenetetrahydrofolate reductase status as interactive determinants of adenomatous and hyperplastic polyps of colorectum. American Journal of Medical Genetics 101, 246-254.

Wainfan E \& Poirier LA (1992) Methyl groups in carcinogenesis: effects on DNA methylation and gene expression. Cancer Research 52, S2071-S2077.
Wargovich MJ, Chen CD, Jimenez A, Steele VE, Velasco M, Stephens LC, Price R, Gray K \& Kelloff GJ (1996) Aberrant crypts as a biomarker for colon cancer: evaluation of potential chemopreventive agents in the rat. Cancer Epidemiology Biomarkers and Prevention 5, 355-360.

White E, Shannon JS \& Patterson RE (1997) Relationship between vitamin and calcium supplement use and colon cancer. Cancer Epidemiology Biomarkers and Prevention 6, 769-774.

Wilson MJ, Shivapurkar N \& Poirier LA (1984) Hypomethylation of hepatic nuclear DNA in rats fed with a carcinogenic methyldeficient diet. Biochemistry Journal 218, 987-990.

Wolf SF \& Migeon BR (1985) Clusters of CpG dinucleotides implicated by nuclease hypersensitivity as control elements of housekeeping genes. Nature 314, 467-469.

Yang AS, Shen JC, Zingg JM, Mi S \& Jones PA (1995) HhaI and HpaII DNA methyltransferases bind DNA mismatches, methylate uracil and block DNA repair. Nucleic Acids Research 23, 1380-1387.

Yebra MJ \& Bhagwat AS (1995) A cytosine methyltransferase converts 5-methylcytosine in DNA to thymine. Biochemistry $\mathbf{3 4}$, 14752-14757.

Yi J, Wang ZW, Cang H, Chen YY, Zhao R, Yu BM \& Tang XM (2001) p16 gene methylation in colorectal cancers associated with Duke's staging. World Journal of Gastroenterology 7, 722-725.

Zapisek WF, Cronin GM, Lyn-Cook BD \& Poirier LA (1992) The onset of oncogene hypomethylation in the livers of rats fed methyl-deficient, amino acid-defined diets. Carcinogenesis 13, 1869-1872. 